\title{
Pola Pendidikan dalam Perspektif Pendidikan Hindu
}

\author{
I Nyoman Sidi Astawa \\ Institut Agama Hindu Negeri Tampung Penyang Palangka Raya \\ sidiastawa@iahntp.ac.id
}

\begin{abstract}
Riwayat Jurnal
Artikel diterima: 24 Maret 2018

Artikel direvisi: 6 Mei 2018

Artikel disetujui: 28 Mei 2018
\end{abstract}

\begin{tabular}{|c|c|}
\hline $\begin{array}{l}\text { Kata Kunci: } \\
\text { Pola Pendidikan } \\
\text { Pendidikan Agama } \\
\text { Agama Hindu }\end{array}$ & $\begin{array}{l}\text { Abstrak } \\
\qquad \text { Tujuan tulisan ini adalah untuk mengali dan memberikan } \\
\text { deskripsi pola pendidikan yang telah diterapkan dalam pendidikan } \\
\text { Hindu. Pola Pendidikan agama Hindu mengunakan ajaran dan konsep- } \\
\text { konsep Hindu sebagai landasan dan inspirasi untuk mengembangkan } \\
\text { pendidikan, baik dari visi, misi, tujuan, capaian pembelajaran (learning } \\
\text { outcome), metode pengajaran, strategi pembelajaran serta metode } \\
\text { evaluasi dalam pendidikan Hindu. Ajaran serta konsep-konsep } \\
\text { pendidikan yang ideal sangat banyak dalam Hindu. konsep-konsep } \\
\text { pendidikan dalam Hindu sepatutnya yang dikembangkan oleh lembaga } \\
\text { - lembaga pendidikan Hindu maupun guru-guru agama Hindu sehingga } \\
\text { pendidikan agama Hindu benar - benar dapat mengwujudkan tujuan } \\
\text { agama dan tujuan manusia dalam dunia ini. }\end{array}$ \\
\hline $\begin{array}{l}\text { Keyword: } \\
\text { Pattern of Education } \\
\text { Religious education } \\
\text { Hindu religion }\end{array}$ & $\begin{array}{l}\text { Abstract } \\
\text { The purpose of this paper is to explore and provide a description } \\
\text { of the patterns of education that have been applied in Hindu } \\
\text { education. The Hindu religious education pattern uses the } \\
\text { teachings and concepts of Hinduism as the foundation and } \\
\text { inspiration for developing education, both from vision, mission, } \\
\text { goals, learning outcomes, teaching methods, learning strategies } \\
\text { and evaluation methods in Hindu education. The teachings and } \\
\text { concepts of ideal education are very much in Hinduism. the } \\
\text { concepts of education in Hinduism should be developed by Hindu } \\
\text { educational institutions as well as Hindu religious teachers so } \\
\text { that Hindu religious education can truly realize the goals of } \\
\text { religion and human goals in this world }\end{array}$ \\
\hline
\end{tabular}




\section{Pendahuluan}

Pendidikan merupakan suatu hal yang sangat penting dalam kehidupan manusia. Manusia berkembang dan tumbuh melalui proses pendidikan baik formal,informal maupun non formal. Pendidikan selalu dilakukan tidak perduli status dari manusia dalam dunia ini. Pendidikan selalu terjadi dalam kehidupan manusia baik manusia yang miskin atau kaya, baik atau buruk, cacat atau tidak cacat, raja atau masyarakat biasa, dan yang lainnya serta manusia beragama apapun termasuk manusia Hindu selalu menjalani pendidikan. Oleh karena itu, tepat gagasan Atmaja (2010, hlm. 58) bahwa manusia adalah mahluk pendidikan (homo educatum).

Lembaga-lembaga pendidikan Hindu dewasa ini telah banyak berdiri dan menjadi tempat proses pendidikan formal berlangsung, baik dari tingkat sekolah tinggi, institut dan universitas negeri dan swasta. Dari perguruan tinggi yang telah ada tersebut telah banyak melahirkan sarjana agama Hindu, magister agama Hindu dan juga Doktor ilmu agama Hindu. Kebanyakan dari sarjana, magister pendidikan agama Hindu telah memiliki kemampuan yang tinggi dan luas mengenai teori pendidikan, strategi pendidikan, metode pembelajaran dan yang lainnya terkait dengan teori dan konsep pendidikan secara umum yang tidak dapat dipungkiri berasal dari Barat.

Keungulan dari sarjana dan magister pendidikan agama Hindu tersebut di satu sisi secara struktural membangakan dan di satu sisi menjadi suatu keanehan bagi masyarakat secara luas terutama non agama Hindu. Kompetensi yang telah dimiliki tersebut justru kurang sesuai dengan label pendidikannya, yaitu pendidikan dalam Hindu. Hal itu mengingat realitas cukup banyak sarjana dan magister pendidikan agama Hindu lebih menguasai pendekatan, teori, strategi, dan metode belajar secara umum (Barat) yang tentunya belum tentu relevan untuk pendidikan agama Hindu dibandingkan dengan pendekatan, teori, strategi, dan metode pembelajaran atau pendidikan Hindu.

Di samping itu, pertanyaan mengenai makna pendidikan agama Hindu jawabannya sangat bervariasi, namun secara umum ada dua jawaban yaitu pertama pendidikan dalam Hindu dan kedua, Hindu dalam pendidikan. Adanya satu permasalahan atau pertanyaan dengan banyak jawaban merupakan suatu tanda adanya suatu permasalahan. Oleh karena itu, penulis sangat tertarik dan merasa penting untuk mengangkat permasalahan mengenai pendidikan agama Hindu. Permasalahan pendidikan Hindu merupakan suatu permasalahan yang sangat penting bagi umat Hindu baik sebagai warga Negara maupun sebagai manusia yang memiliki dua dimensi yaitu sakala dan niskala. Praktik-praktik pendidikan agama Hindu 
baik disekolah-sekolah umum maupun di sekolah-sekolah keagamaan dewasa ini fungsinya sangat sering dipertanyakan oleh masyarakat.

Pertanyaan-pertanyaan mengenai fungsi pendidikan agama adalah terkait dengan realita kehidupan dalam dunia pada umumnya dan Indonesia pada khususnya. Banyaknya kasus yang terjadi dewasa ini seperti korupsi, kolusi, nepotisme, tindak kriminal, perbuatan asusila yang sering terjadi di dalam masyarakat tidak lain adalah dilakukan oleh oknumoknum yang beragama di Indonesia termasuk di dalamnya juga oleh oknum-oknum umat Hindu. Suatu gugatan kritis yang dilontarkan Mangunwijaya (dalam Sukayasa, 2011, hlm. 2) yakni apakah arti agama bila tidak mampu berprikemanusiaan? apa arti agama tanpa religiusitas, tanpa penuntunan manusia ke arah segala yang baik. Permasalahan yang sering muncul dan menjadi pemikiran penulis dan juga banyak dari masyarakat mengenai pendidikan agama Hindu.

Persoalan tersebut muncul dalam bentuk pertanyaan yaitu apakah pendidikan agama Hindu bermakna pendidikan dalam Hindu atau Hindu dalam pendidikan? Dalam rangka menjawab pertanyaan tersebut akan dilakukan studi kepustakaan terhadap beberapa bukubuku seperti yang ditulis oleh Titib (1996) Veda Sabda Suci: Pedoman Praktis Kehidupan O’Sullivan (1997) Vedic Education (Gurukula) in Contemporary Context: Consideration for a Krisna Concious Thinking Curriculum, Jayapalan (2005) History of Education in India, Dvivedi (1994) Evolution of Education Thought in India; Amala, Annie, Anupama, \& Rao, (2004) History of Education, Altekar (2009) Education in Ancient India, Mookerji, (2003)

\section{Ancient Indian Education.}

Guna untuk menjawab permasalahan tersebut di atas, maka pustaka-pustaka tersebut akan dikaji dengan mengunakan perspektif ilmu agama Hindu, dengan pendekatan interdisipliner, yaitu memadukan pendekatan ilmu berupa teori-teori atau konsep-konsep non agama dengan teori atau konsep-konsep agama Hindu, sehingga permasalahan yang dikaji dalam hal ini dapat dipahami secara lebih lengkap dan gamblang.

\section{Pendidikan Dalam Hindu: Hindu Sebagai Subjek}

Ada baiknya sebelum membahas pendidikan Hindu terlebih dahulu dilihat beberapa pendapat mengenai pendidikan agama seperti pendidikan agama Islam sebagai bahan perbandingan. Adapun beberapa pendapat mengenai pendidikan agama Islam adalah sebagai berikut. 
1. Ahmad D. Marimba menegaskan pendidikan Islam adalah bimbingan jasmanai dan rohani berdasarkan hukum-hukum Islam menuju terbentuknya kepribadian utama menurut ukuran-ukuran Islam.

2. Usman Said bahwa pendidikan agama Islam ialah segala usaha untuk terbentuknya atau membimbing /menuntun rohani jasmani seseorang menurut ajaran Islam

3. Abd. Rahman Shaleh, pendidikan Islam ialah segala usaha yang diarahkan kepada pembentukan kepribadian anak yang merupakan dan sesuai dengan ajaran Islam.

4. H.Zuhairini, pendidikan agama berarti usaha-usaha secara sistematis dan pragmatis dalam membantu anak didik agar mereka hidup sesuai dengan ajaran Islam ((Ahmadi \& Uhbiyati, 1991)

Selain pendapat-pendapat tersebut, penting juga mengetahui bagaimana ilmu Islam dan Barat menurut Bagir dan Abidin (dalam (Tutik \& Trianto, 2008) menyatakan bahwa:

Pertama, Umat Islam butuh sebuah sistem sains (ilmu pengetahuan) untuk memenuhi kebutuhan-kebutuhan baik material atu spiritual. Sementara ini sistem sains modern mengandung nilai-nilai Barat yang tidak sesuai dengan nilai-nilai Islam....Kedua, secara sosiologis umat Islam yang tinggal di wilayah geografis dan memiliki kebudayaan yang berbeda dari Barat jelas Butuh sistem sains yang berbeda pula. Ketiga, umat Islam pernah memiliki suatu peradaban yang islami dimana sains berkembang sesuai dengan nilai dan kebutuhan umat Islam. Kini umat Islam tinggal bersungguh-sungguh untuk menciptakan kembali sains peradaban Islam yang islami pula.

Gagasan mengenai pendidikan Islam disampaikan pula oleh Mas'ud (2002, hlm. 44) bahwa "Pendidikan Islam harus mengacu pada ajaran dasar Islam itu sendiri..." Pendapat yang serupa juga dinyatakan oleh Sadulloh (2004) bahwa "Pendekatan religi terhadap pendidikan, berarti bahwa suatu ajaran religi dijadikan sumber inspirasi untuk menyusun teori atau konsep-konsep pendidikan yang dapat dijadikan landasan untuk melaksanakan pendidikan."

Pendapat dan gagasan pendidikan agama Islam dan ilmu Islam di atas tentunya dapat menginspirasi dalam hal pendidikan agama Hindu. Dengan mengunakan perbandingan pendapat dan gagasan tersebut, maka pendidikan agama Hindu seharusnya mengacu pada ajaran Hindu atau Veda dan sistem pendidikan Hindu harus sesuai dengan pendidikan Hindu dalam pengertian pendidikan dalam pandangan Hindu bukan Hindu dalam pandangan pendidikan. Agama Hindu memiliki banyak hal mengenai pendidikan agama Hindu. Ajaran Hindu dalam Bhagawad Gita (Pudja, 2003, hlm. 105) bahwa:

Ajaran yang Abadi ini aku turunkan kepada visvan, visvan mengajarkan kepada manu, dan manu menerangkannya kepada Iksvaku (Bhagavad Gita IV.1)

Menurut Prabupada (1983) Bhagavadgita (Ajaran Hindu) dipelajari ialah melalui parampara atau garis perguruan. Selain itu, kajian Atmaja (2010) menegaskan bahwa teks 
suci Veda dan tafsirannya, tidak saja memuat tentang tata kelakuan keagamaan, tetapi memuat pula aneka tata kelakuan sosial, antara lain tentang pendidikan." Ajaran agama Hindu mengklasifikasikan ilmu pengetahuan/pengetahuan menjadi dua kategori kelompok besar secara umum, yaitu paravidya dan aparavidya (Kasturi, 1998, hlm. 26).

Ajaran Hindu memberikan penjelasan bahwa yang transenden meliputi semuanya termasuk manusia. Oleh karena itu, dalam ilmu pengetahuan tidak bisa diabaikan. Agama Hindu sesungguhnya memiliki banyak teori atau konsep-konsep yang berhubungan dengan pendidikan. Konsep-konsep pendidikan yang terdapat dalam Hindu diantaranya adalah (Machwe dalam (A. T. Atmaja \& Atmaja, 2008):

1. Sa vidya ya vimuktaye (pembelajaran adalah yang membebaskan manusia)

2. Vidya trinity netrah (pembelajaran seperti mata ketiga)

3. Vidyayamrihtamashnute (pembelajaran membuat manusia abadi)

4. Na hi jnanen sadrishnham pavitramih vidyate (tidak ada yang lebih murni di dunia ini dari pada pengetahuan)

5. Vidya balam chandrabalamstahtaiva (mudah-mudahan kekuatan pengetahuan dan kekuatan bulan menganugerahi anda sekalian)

6. Vidya gurunam guruh (pengetahuan adalah gurunya guru)

7. Kim kim na sadhyati kalpalateva vidya (apa yang tidak dijumpai oleh pembelajaran itu? Ia merupakan sebuah tumbuhan magis atau pohon kebijaksanaan)

8. Vidya vihinah pashuh (seseorang yang tanpa pembelajaran adalah binatang)

Selain pendapat Machwe yang dikutip Atmaja di atas dalam Hindu juga memiliki istilah - istilah pendidikan seperti dinyatakan oleh Dvivedi (1994, hlm. 2) sebagai berikut.

The term for education in ancient literature are as follows:

Adhyayana-to go near (to some teacher for education)

Prabodha-awaking or enlightenment

Siksha-to learn, to recite

Upanayana-the initiation ceremony meaning taking near

Vinaya-to lead out in a particularly way

Kitab suci Veda sebagai sumber ajaran dan pengetahuan agama Hindu memiliki peranan penting dalam mempelajari pendidikan dalam agama Hindu. Pentingnya peranan dan kedudukan Veda dalam pendidikan Hindu sangat jelas terlihat dari arti Veda itu sendiri. Veda merupakan suatu yang memiliki arti atau makna pengetahuan atau ilmu pengetahuan. Keterkaitan Veda dengan pendidikan Hindu jelas terlihat dari pengertian atau makna kata Veda sebagai pengetahuan tersebut.

Pengetahuan merupakan sesuatu tujuan utama dari suatu pendidikan. Tidak mungkin ada pendidikan tanpa adanya pengetahuan. Bahkan Rao \& Babu (2004, hlm. 4) menyatakan bahwa "The characteristic of vedic education are:Education is knowledge. It is man third eye." Pandangan pendidikan Veda yang secara langsung juga merupakan pendidikan Hindu 
mengenai pendidikan diartikan sebagai pengetahuan dan pengetahuan dinyatakan sebagai mata ketiga manusia dalam pendidikan agama Hindu menunjukkan bahwa pendidikan dan pengetahuan merupakan sangat penting dalam kehidupan manusia. Pengetahuan dinyatakan sebagai mata ketiga dalam pandangan Hindu sudah pasti memiliki dasar logika yang jelas.

Pengetahuan bagi siapapun tidak dapat dipungkiri merupakan jendela manusia untuk melihat segala sesuatu baik di luar diri manusia maupun dalam diri manusia itu sendiri. Prinsip dasar dari pengetahuan merupakan sebagai alat untuk mengetahui sesuatu. Pendapat tersebut sejalan dengan gagasan Piaget (dalam Suparno, 1997) menyatakan bahwa pengetahuan merupakan skemata-skemata yang dimiliki oleh manusia untuk mengenali atau mengetahui sesuatu yang belum diketahui atau dilihat sebelumnya. Pendapat yang serupa juga dinyatakan oleh Bourdeu (Haryanto, 2012, hlm. 220) yaitu dengan konsep habitusnya.

Pengetahuan yang diperoleh melalui pendidikan Hindu ialah dengan system pendidikan Veda atau sering juga disebut sistem pendidikan gurukula. Dinamakan sistem pendidikan Veda karena pendidikan Hindu berbasis untuk pengajaran pengetahuan yang terdapat dalam Veda. Dinyatakan sebagai sistem pendidikan gurukula karena pendidikan berlangsung dengan tinggal dan menjadi keluarga guru. Dalam pendidikan Hindu juga mengenal adanya lembaga-lembaga pendidikan yang disesuaikan juga dengan bidang yang dikaji seperti dinyatakan oleh Jayapalan (2005, hlm. 11) sebagai berikut.

1. Branch or shakha-denotes all the three branches of Veda

2. Charans- according to Panini only a group of disciples who studied in one branch or, shakha was charan

3. Parishad- the word parishad means all things expanded on all side. In order word it has been used for a conference of learned men

4. Gotra or kula-it was based on family traditions which might be real or imaginary various gotra or kula were related to ancient Risis

\section{Objek Materi dalam Pendidikan Hindu}

Objek materi adalah lapangan atau bahan penyelidikan suatu ilmu (Wardana \& Relin, 2004, hlm. 5). Susanto (2011, hlm. 81) menyatakan bahwa “Objek materi berupa bendabenda materiil maupun nonmaterial, bahkan bisa juga berupa hal-hal, masalah-masalah, ideide, konsep-konsep dan sebagainya." Pendidikan Hindu juga memiliki objek materi sebagai bahan kajiannya. Objek materi pendidikan agama Hindu dapat dilihat dari siapa yang melakukan dan perlu pendidikan. Pendidikan Hindu dilakukan untuk mendidik manusia dalam hal ini ialah umat Hindu. Dengan demikian, objek materi pendidikan Hindu adalah manusia Hindu. Oleh karena itu, pendidikan Hindu supaya dapat mencapai tujuan dan 
capaian pembelajarannya dengan tepat dan baik memerlukan suatu pemahaman terhadap apa itu manusia.

Manusia memiliki pengertian mahluk yang memiliki pikiran atau mahluk berpikir. Dalam konsep Hindu manusia dinyatakan memiliki dua dimensi yaitu nyata dan tidak nyata atau sakala dan niskala. Dalam ajaran Hindu mengenai penciptaan manusia dinyatakan bahwa manusia memiliki unsur purusa atau jiwa atau kesadaran dan prakerti atau ketidaksadaran atau materi. Selain jiwa juga terdapat unsur yang sifatnya tidak tampak yaitu manah dan budhi. Sedangkan unsur materi adalah panca mahabhuta yaitu akasa, bayu, teja, apah, pertiwi (Lubis, 2004, hlm. 55; Ra, 2004, hlm. 19).

Manusia dalam konsep Hindu merupakan suatu mahluk yang berpikir yang memiliki tiga guna atau sifat dalam dirinya. Dengan demikian, dapat dinyatakan bahwa manusia tidak dapat dilihat hanya sebagai sesuatu yang sama dengan benda alam lainnya. Walaupun tidak dapat dipungkiri bahwa manusia juga memiliki unsur materi yang sifatnya sama dengan benda alam lainnya, sehingga memungkinkan dapat dipandang secara positivisme seperti ditegaskan oleh (Lubis, 2004, hlm. 55) bahwa bila manusia hanya direduksi tataran biologiskimiawi saja, maka paradigma positivis kiranya tepat digunakan.

Berdasarkan pendapat Lubis tersebut, maka pendekatan positivisme yang menekankan segala sesuatunya harus dapat teramati dan terukur kurang tepat digunakan dalam pendidikan agama Hindu. Pendidikan agama Hindu memandang objek materi pendidikan yaitu manusia sebagai sesuatu dualitas yang tidak dapat dipisahkan, sehingga perlu dikaji secara holistik. Manusia bagi agama Hindu merupakan mahluk hidup yang memiliki jiwa, pikiran, akal, budi, sifat/guna, panca tanmatra dan pancamahabuta. Manusia juga memiliki kemampuan atau kecerdasan untuk membedakan yang baik dan yang tidak baik. Dari pandangan manusia sebagai objek pendidikan Hindu, maka pendekatan dan metodenya tidak dapat disamakan dengan pendekatan benda-benda alam seperti yang digagas oleh kaum positivis.

\section{Tujuan Pendidikan dalam Hindu}

Salah satu pokok tujuan pendidikan adalah mendapatkan pengetahuan yang dalam konteks Hindu disebut pengetahuan yang benar guna menghilangkan pengetahuan yang tidak benar atau istilahnya pengetahuan perlu dimiliki untuk menghilangkan kebodohan atau meminjam gagasan Piliang (2008, hlm. 323) simulakrum realitas yaitu realitas yang telah menyimpang dari kehendak Tuhan. Menurut Machwe (2000, hlm. 96) kelima pengetahuan yang salah adalah sebagai berikut. 
1. Avidya, sang diri bersifat abadi, murni dan penuh kebahagiaan. Akan tetapi untuk melihatnya sebagai nonabadi, tidak murni, atau penuh dengan penderitaan adalah ketidak tahuan

2. Asmita, untuk mengidentifikasi prakerti dan purusha untuk mempercayai bahwa tidak ada perbedaan di antara keduanya

3. Raga, kemelekatan akut terhadap kenikmatan-kenikmatan duniawi

4. Doesha, kemarahan karena irihati dan kecemburuan

5. Abhinivesha, upaya ekstra yang sebenarnya tidak perlu karena rasa ketakutan terhadap kematian

Tujuan pendidikan agama Hindu tidak dapat dipisahkan dari tujuan agama Hindu. Tujuan agama Hindu ialah untuk mendapatkan moksa dan jagadita (Puniatmadja, 2002; Suhardana, 2007, hlm. 9), Moksa ialah pembebasan atma atau jiwa dari samsara (Pandit, 2001, hlm. 120; Suhardana, 2006, hlm. 47). Moksa juga dapat diartikan sebagai penyatuan atma dengan Brahman (Puniatmadja, 2002, hlm. 79). Moksa menjadi tujuan akhir kehidupan manusia (Somvir, 2001, hlm. 55).

Jagatdita ialah kebahagiaan atau kesejahteraan dalam dunia. Kesejahteraan merupakan salah satu tujuan dalam kehidupan manusia dalam dunia ini. Makna kesejahteraan sering salah dipahami oleh manusia. Kesejahteraan sering dimaknai sama dengan kaya. Sehingga sering dinyatakan orang yang kaya adalah orang yang sejahtera. Oleh karena itu, apabila ingin sejahtera, maka harus memperkaya diri. Padahal sesungguhnya sejahtera dan kaya memiliki perbedaan. Pendapat tersebut sesuai dengan pendapat (A. T. Atmaja \& Atmaja, 2008) perbedaan sejahtera dan kaya seperti terlihat dalam tabel berikut.

\begin{tabular}{|c|c|}
\hline$K A Y A$ & SEJAHTERA \\
\hline $\begin{array}{l}\text { Kaya berarti memiliki banyak uang dan } \\
\text { asset, misalnya rumah, sepeda motor, } \\
\mathrm{TV} \text {, mobil, penampilan modis, gaya } \\
\text { hidup mewah, dll }\end{array}$ & $\begin{array}{l}\text { Sejahtera berarti hidup aman dan damai, } \\
\text { sebab seseorang bisa memenuhi kebutuhan } \\
\text { hidup (bukan keinginan) sehari-hari } \\
\text { dengan pendapatannya }\end{array}$ \\
\hline $\begin{array}{l}\text { Kaya bisa murni atau bisa pula semu. } \\
\text { Kaya murni berarti memiliki asset tanpa } \\
\text { utang. Sebaliknya kaya semu berarti } \\
\text { memiliki banyak asset, namun kotor, } \\
\text { karena harus dipotong dengan utang. } \\
\text { Jadi penampilan kaya, namun terbelit } \\
\text { utang, karena lebih besar pasak daripada } \\
\text { tiang }\end{array}$ & $\begin{array}{l}\text { Pemenuhan kebutuhan hidup secara } \\
\text { merdeka. Pengeluaran lebih kecil atau } \\
\text { seimbang dengan pendapatan. Ukuran } \\
\text { kesejahteraan memang relatif, tapi yang } \\
\text { penting adalah bagaimana seseorang bisa } \\
\text { hidup layak, tanpa berutang atau bukan } \\
\text { lebih besar pasak daripada tiang. }\end{array}$ \\
\hline
\end{tabular}


Gagasan Atmaja yang membedakan makna kaya dengan sejahtera pada tabel di atas sejalan dengan pandangan Hindu dimana dalam ajaran Hindu diajarkan bahwa kehidupan sejahtera tidak mesti harus kaya, walaupun ajaran agama Hindu tidak melarang orang menjadi kaya. Pendidikan Hindu juga dimaksudkan untuk memberikan pencerahan bagi para siswa dalam keseimbangan aspek-aspek dalam diri manusia. Hal tersebut dinyatakan oleh Amala dkk. (2004, hlm. 35) menyatakan bahwa "Education was regarded as a source of illumination and power which transforms and ennobles over nature by progressive and harmonious development of our physical, mental, intellectual and spiritual faculties." Selain disesuaikan dengan tujuan agama yang menjadi patokan adalah tujuan hidup manusia.

Tujuan hidup manusia juga merupakan penurunan dari tujuan agama yang sifatnya lebih mendetail atau istilah ilmiahnya merupakan konsep-konsep dan variabel yang menjadi panduan manusia untuk mencapai tujuan agama. Secara intinya pengklasifikasian tujuan manusia juga secara umum dibedakan menjadi kategori tujuan dalam dunia dan juga tujuan di alam setelah kematian. Tujuan hindup manusia yang dituangkan dalam ajaran Hindu bersifat sistematis yaitu dari urutan dasar sampai tujuan tertinggi dari manusia.

Tujuan hidup manusia dirumuskan dalam suatu konsep yang dinamakan catur purusha artha yang berarti empat tujuan hidup manusia. Tujuan hidup manusia yang terdapat dalam rumusan catur purusa artha ialah dharma, artha, kama dan moksa (Awanita, 2003, hlm. 12; Suhardana, 2010, hlm. 64). Keempat tujuan ini tertuang dalam jenjang kehidupan yang disebut catur asrama yang berarti empat tingkatan dalam kehidupan manusia. Catur asrama terdiri dari brahmacari, grahasta, vanaprasta dan bhiksuka atau sanyasin (Somvir, 2001, hlm. 57; Sukhabodhananda, 2006, hlm. 72).

Brahmacari ditempatkan sebagai jenjang awal dalam kehidupan manusia dalam tingkatan hidup yang harus dijalani oleh manusia, bukan merupakan suatu kebetulan. Penempatan brahmacari dalam jenjang pertama telah melalui suatu pemikiran yang dalam dan penuh dengan pertimbangan. Para maharsi yang memetakan jenjang kehidupan dalam konsep catur asrama merupakan seorang yang suci, selain itu seorang rsi bukanlah sembarang orang, tetapi seseorang yang telah memiliki kemampuan dan pengetahuan tinggi sehingga apa yang dikonsepkan oleh para maharsi merupakan suatu hal yang terbaik dalam kehidupan manusia sesuai dengan kontekstual sosial masyarakatnya.

Menurut Jyoti (2012, hlm. 7) menyatakan bahwa oleh sebab itu untuk mencapai kelepasan (kebahagiaan) perlu memiliki pengetahuan yang benar karena memiliki pengetahuan saja tidak cukup, namun harus memiliki pengetahuan yang benar. Penempatan tahap brahmacari sebagi tahap pertama dalam kehidupan manusia itu menandakan juga 
bahwa agama Hindu telah mennyadari tentang pentingnya pendidikan seperti yang dinyatakan (N. B. Atmaja, 2010) bahwa realitas ini disadari oleh agama Hindu, terbukti dari kenyataan bahwa agama Hindu banyak mengkaji masalah pendidikan. Tujuan pendidikan Hindu secara rinci dinyatakan oleh Shukla (2004, hlm. 73) sebagai berikut.

The major aims of ancient education, oriented toward value development are as under: To promote understanding of the moral value of life.

To provide religious environment of attending emancipation under the gaiden guru

To provide pupil with character and to lead disciplined and spiritual life.

To train individuals self-reliant economicly.

To promote happiness and righteousness of the individuals

To enable one toward realization of the identity of atman (individual soul) and Brahman (universal soul).

To infuse the quality of peity and religiousness in the mind of the people.

To preserve and spread national heritage and culture.

To propagate eternal values like truth, non-violance and mental happiness.

To impart education of certain subjects like medicine, astrologyart, philosophy, archery, etc.

Filial relationship between guru and disciples.

Fre education

To develop equal-mindedness and to cultivate highest type of love.

Rincian tujuan pendidikan Hindu yang nyatakan oleh Shukla tersebut terlihat bahwa tujuan pendidikan agama Hindu adalah komprehensip atau lengkap yang berhubungan dengan pencapaian dari tujuan manusia yang terangkum dalam konsep catur purusha arta. Selain itu juga sekaligus, sejalan dengan tujuan agama Hindu yakni jagatdita dan moksa.

\section{Guru dalam Agama Hindu}

Guru merupakan seseorang yang patut dimuliakan atau pembimbing spiritual (Suhardana, 2010, hlm. 1). Pendapat tersebut sejalan dengan pendapat Altekar (2009) yang menyatakan bahwa "the idea that the guru or teacher is the spiritual father, which is quite common in the Smriti literature, occurs as early as the Atharvaveda, and the Baudhayana Dharmasastra declares that a Srotriya or scholar, who teaches pupil, cannot be deemed tobe issueless". Guru dalam pandangan Hindu adalah seseorang yang memiliki kualitas yang tinggi dalam berbagai aspek.

Pendapat tersebut sesuai dengan pendapat Jayapalan (2005, hlm. 5) bahwa "Teachers of the vedic age, were men of highest caliber in society from the point of knowledge and spiritual progress." Pendapat tersebut mensyaratkan bahwa seorang guru merupakan orang yang memiliki tingkat pengetahuan dan berkarakter baik yang bertindak berdasarkan ajaran- 
ajaran kebaikan dalam agama.Kemampuan tersebut bukan saja berdasarkan jenjang pendidikan yang tinggi dan pengetahuan agamanya yang banyak.

Dalam Veda dinyatakan mengenai seorang guru (Titib, 1996, hlm. 431) sebagai berikut.

Orang yang berpengetahuan tinggi memiliki cahaya yang rahasia. Rgveda VII.76.4

Seorang sarjana/guru memiliki pengetahuan yang dalam dan kekuatan membedakan yang baik dan buruk. Dia bijaksana. Rgveda IX.107.7

Tugas guru juga dinyatakan oleh Titib (1996, hlm. 429), yakni:

Guru memberikan pendidikan dan pengetahuan kepada yang bodoh, memajukan pengetahuan dan keterampilan, memiliki pengetahuan untuk membedakan yang baik dan yang buruk (bagi anak didik), memiliki wawasan ke depan, bijaksana dan menjadi pemimpin masyarakat, penerus kebenaran, orator yang cemerlang, memajukan ilmu pengetahuan, mendidik moralitas anak didik, mengkondisikan agar anak didik mengikuti ajaran suci Veda, melindungi tradisi suci.

Pendapat Titib tersebut sejalan dengan ajaran-ajaran dalam kitab suci Veda diantaranya adalah sebagai berikut (Titib, 1996).

Wahai umat manusia, engkau dilahirkan bersama fajar.berilah pengetahuan kepada orang-orang yang bodoh dan berilah kecantikan kepada orang-orang yang buruk rupa (Rgveda I.6.3).

Ya Sanghyang Waruna, majukanlah intelek para siswa dan tanamkanlah pengetahuan dan ketangkasan kepada mereka (RgvedaVIII.42.3).

Seorang sarjana atau guru memiliki pengetahuan yang mendalam dan kekuatan membedakan yang baik dan buruk. Dia bijaksana. (Rgveda IX.107.7).

Kami harus mengajar para siswa yang patuh setiap hari (Rgveda VII.32.19)

Guru dalam pendidikan agama Hindu merupakan orang yang memiliki kesempurnaaan dalam hal pengetahuan duniawi (aparavidya) dan juga pengetahuan rohani (paravidya). Seorang guru juga memiliki kemapuan yang koprehensip baik secara teoritis sekaligus praktisnya. Hal itu mengingat pendidikan Hindu bukan saja mengenai membuat siswa mengetahui dalam tataran kognitif tetapi juga mengenai kemampuan siswa untuk mengaplikasikan pengetahuan yang dimilikinya atau yang diketahuinya. Guru dalam pandangan Hindu dianggap sebagai perwujudan Tuhan dalam dunia. Oleh karena itu kedudukan guru dalam masyarakat Hindu memiliki posisi sangat penting. Seorang raja sekalipun menghormati keberadaan guru dalam pendidikan agama Hindu. 


\section{Siswa dalam Pendidikan Hindu}

Seseorang yang telah cukup umur dan waktunya untuk melanjutkan pendidikan, maka seseorang selanjutnya menentukan dan mencari seseorang yang akan dijadikan guru tempat seseorang akan menimba ilmu. Proses ini, dalam konteks dewasa ini adalah seseorang yang memilih sekolah dimana dia akan menjalani pendidikan. Pada jaman dulu dinyatakan mencari guru karena pada saat itu pendidikan dilakukan oleh gurukula yaitu tinggal bersama guru dalam keluarga guru. Setelah seseorang menentukan atau memilih gurunya selanjutnya sebelum menjadi bagian dalam gurukula seseorang yang akan belajar mengikuti upacara upanayana. Upacara upanayana merupakan suatu upacara menandai diterimanya siswa oleh guru. Secara etimologi upanayana berarti mendekatkan diri dalam arti dekat kepada guru. Selama menuntut ilmu siswa memiliki tugas-tugas yang perlu dilaksanakan dengan disiplin yang tinggi.

Tugas dan disiplin yang berat tersebut memerlukan suatu energi yang banyak hal itu mungkin yang ingin disampaikan Veda tentang perlunya menjaga dan memelihara energi untuk mendapatkan pengetahuan seperti yang dinyatakan Dvivedi (1994, hlm. 31) bahwa "The vedic literature advises student to preserve his energy to acquire the great store of knowledge." Selanjutnya siswa dalam menjalani pendidikan sesuai pendapat Mookerji (2003) bahwa "The pulpil must find the teacher. He must live with him as a member of family and is treated by him in every way as his son." Pendapat lain mengenai yang dilakukan siswa pada masa menjalani pendidikannya disampaikan oleh Prabupada seperti dikutip O’Sullivan (1997) menegaskan bahwa "A student should practice completely controlling his sense. He should be submissive and should have an attitude of firm friendship for the spiritual master. With a great vow, the brahmacari should live at the gurukula, only for the benefit of the guru." Para siswa memasuki jenjang kehidupan brahmacari asrama. Pada masa menjadi siswa, seseorang benar-benar harus mentaati tata aturan yang diwajibkan dalam kehidupan brahmacari. Segala kewajiban harus dilaksanakan dan ditaati tidak boleh dilanggar oleh para siswa.

Para siswa juga harus memiliki kontrol terhadap pikiran seperti ditegaskan oleh (Sivananda, 1984, hlm. 122) bahwa "brahmacarya is absolute freedom from sexual thought and desires. It is the vow of celibacy. It is control of all the senses in thought, word and deed. It is meant for both men and women." Pendapat Sivananda tersebut menunjukan bagaimana siswa dalam masa brahmacari harus benar-benar terbebas hal-hal seperti seksual dan pikiranpikiran yang tidak diperbolehkan lainnya. Siswa sebagai seorang brahmacari dalam hindu 
terdapat kategori-kategori tertentu seperti dinyatakan oleh Dvivedi (994, hlm. 31) bahwa "The student who returned home after completing his study was called upkurvana brahmacari. Some student carried studies for their whole life residing at the teacher's were called naisthika brahmacari." Pendapat Dvivedi tersebut jelas menunjukan ada dua klasifikasi brahmacari atau siswa dalam gurukula. Kedua kelompok atau jenis brahmacari yaitu upkurvana dan naisthika brahmacari.

Pembagian jenis brahmacari tersebut dilihat dari waktu pendidikannya. Berdasarkan pendapat Dvivedi tersebut waktu pendidikan dalam pendidikan Hindu pada jaman dahulu yaitu seseorang yang menjadi siswa sampai hanya selama pendidikan dimana lama pendidikan tergantung dari kedalaman ilmu atau pengetahuan serta kemampuan siswa dalam menuntut ilmu. Amala dkk. (2004, hlm. 43) menegaskan bahwa "Those obtaining education upto the age of 24-Vasu;those obtaining education upto the age of 36-Rudra; those obtaining education upto age of 48-Aditya." Setelah siswa menyelesaikan pendidikannya mereka akan kembali kepada keluarganya dan masyarakat seperti masyarakat lainnya.

Segala sesuatu yang mengikat dan tata aturan yang dilaksanakan dalam masa pendidikan tidak lagi mengikat mereka, termasuk masalah seksualitas. Jika pada masa brahmacari mereka tidak diperbolehkan menikah, maka pada saat selesai pendidikan mereka diperbolehkan menikah. Hal tersebut sesuai dengan tingkatan kehidupan dalam catur asrama dimana setelah selesai masa brahmacari, maka tahapan kehidupan selanjutnya adalah memasuki kehidupan berumah tangga. Akan tetapi, berdasarkan pendapat Dvivedi di atas menunjukan bahwa tidak semua siswa setelah selesai mereka kembali kepada keluarga atau ke rumahnya, tetapi mereka tetap tinggal bersama gurunya sepanjang hidupnya untuk mengabdi kepada gurunya.

\section{Hubungan Guru dan Siswa}

Hubungan guru dan siswa meminjam gagasan strukturalis (Haryanto, 2012, hlm. 273) merupakan suatu bentuk oposisi biner, sehingga hubungan tersebut tergantung pada posisi dalam struktur antara guru dan siswa. Hubungan guru dan siswa ialah seperti pemberi ilmu dan penerima ilmu, yang tahu dan yang tidak tahu, tinggi dan rendah, yang dihormati dan yang menghormati. Guru merupakan orang yang membimbing dan mendidik siswa dengan penuh keikhlasan dan ketulusan dan mengangap siswa sebagai putranya sendiri. Guru dalam pendidikan tidak mengharapkan upah atau gajih kepada siswanya dalam pengajarannya. Guru memiliki tanggung jawab terhadap pengajaran yang dilakukannya supaya siswa yang selesai pendidikan memiliki kualitas yang tinggi. Tugas guru memberikan pengetahuan dan 
keterampilan yang berguna dalam kehidupan siswanya dalam masyarakat dan masyarakat memperoleh manfaatnya.

Guru memperlakukan siswa seperti anaknya sendiri dan tidak ada pembedaan siswa selama pendidikan. Gagasan tersebut sesuai dengan pendapat Mookerji (2003) bahwa "The pupil must find the teacher. He must live with him as a member of his family and is treated by him in every way as his son." Guru tidak pernah membedakan apakah siswanya anak raja, atau anak petani, anak orang kaya atau miskin. Hal tersebut sangat jelas dinyatakan oleh Canakya (Prabupada, t.t., hlm. 210) dengan ungkapan "Putrams ca sisyam ca” keduanya baik anak maupun siswa layak dipilih secara sama untuk menerima Hak warisan ayah atau guru.

Guru selalu mengawasi dan menjaga siswanya dengan baik, baik perkembanagn fisik, prilaku, mental, spiritual dan pengetahuannya. Dalam hubungannya guru sebagai orang tua dan siswa sebagai anak, guru akan memberlakukan siswa sebagaimana orang tua memperlakukan anaknya. Guru akan tegas kepada siswa dalam hal disiplin, apabila siswa melakukan kesalahan maka siswa tersebut diberikan sanksi yang bersifat konstruktif. Guru juga akan memberikan pengajaran dan pelajaran kepada siswa seperti sorang tua yang mengajari anaknya. Dalam pengajaran seperti itu, guru akan memberikan pengetahuan sepenuhnya dan semaksimal mungkin tanpa ada sesuatu yang dirahasiakan atau tidak diberikan. Selama dalam pendidikan siswa mentaati segala perintah dan mengikuti petunjuk yang diberikan oleh guru. Siswa juga melayani guru dengan penuh rasa bhakti dan hormat selayaknya orang tua sendiri. Siswa melaksanakan setiap yang diperintahkan guru penuh dengan ketulusan sebagai suatu kewajiban bukan sebagai suatu beban. Siwa melayani guru dengan membantu memenuhi keperluan dalam kehidupan selama pendidikan, misalnya menyiapkan tempat dan sarana pemujaan, menyiapkan makanan, dan lainnya.

\section{Metode Pengajaran}

Pengajaran dilakukan dengan penekanan pada disiplin yang tinggi. Penekanan disiplin tentunya memiliki makna yang positif bagi hubungan guru dan siswa serta bagi pembentukan serta pencapaian tujuan pendidikan. Hal tersebut sangat jelas ditegaskan oleh Canakya (Prabupada, t.t., hlm. 36) bahwa "terlalu banyak kelonggaran akan mengakibatkan banyak kesalahan, sedangkan ketegasan akan membentuk watak yang baik. Karena itu bersikaplah tegas kepada anak atau murid (siswa), jangan longgar”.

Pendidikan sistem Veda atau gurukula menerapkan beberapa metode dalam pengajarannya. Metode yang digunakan disesuaikan dengan tujuan pembelajaran dan juga disesuaikan dengan capaian pembelajaran yang akan diperoleh oleh siswa. Pengajaran oleh 
guru dalam sistem pendidikan Hindu adalah mendengarkan ajaran guru, merenungkan apa yang diajarkan guru, dan merealisasikan atau mempraktekan ajaran guru. Metode tersebut seperti dinyatakan oleh Singh \& Nath (2007, hlm. 27) bahwa "The Process of education passed through the three stages of comprehension, Meditation, memory and nihi-dhyasana." Pendapat yang senada juga dinyatakan oleh Jayapalan (2005, hlm. 13) bahwa "Mental education also had three stage: (1) Sravan (hearing), (2) Manan (Meditation), and (3) Nidisdhyasan (Realisation)."

Sravana ialah pengajaran yang dilakukan oleh guru bentuk siswa mendengarkan apa yang disampaikan oleh guru dengan penuh perhatian. Guru akan menyampaikan pengetahuan dengan cara lisan atau dharmavacana dan para siswa mendengarkan dengan penuh perhatian dan sungguh-sungguh. Hal itu karena pendidikan sangat menekankan disiplin dan gurupun menerapkan disiplin kepada siswanya dengan ketat. Metode sravana dalam konteks pendidikan dewasa ini dapat disamakan dengan metode ceramah.

Metode manan atau meditasi merupakan salah satu metode yang penting dalam pendidikan Hindu. Ilmu penegtahuan dapat diperoleh melalui kegiatan-kegiatan perenungan sesuai dengan pendapat Jaman (2007, hlm. 37) bahwa ilmu pengetahuan yang diperoleh melalui renungan dan meditasi yang mendalam. Meditasi menjadi suatu tradisi terkenal sampai era modern ini sebagai salah satu metode untuk memusatkan pikiran dan menenangkan diri serta merefleksi segala sesuatu termasuk merefleksi diri.

Dalam pendidikan Hindu metode ini digunakan setelah metode mendengarkan atau sravan. Pengetahuan yang telah disampaikan oleh guru selanjutnya direfleksikan oleh para siswa dengan melakukan meditasi terhadap apa yang telah disampaikan tersebut. Siswa merenungkan dan berusaha mencari serta menemukan makna dari apa yang disampaikan guru. Dalam proses meditasi atau merenungkan materi yang disampaikan guru para melakukan kegiatan refleksi dan analisis, sehingga pemahaman dan pengetahuan yang diperoleh menjadi lebih mantap dan baik.

Meditasi dilakukan untuk pemusatan pikiran dan pencurahan sepenuhnya terhadap objek pengetahuan yang dikaji sehingga dengan terfokus dan konsentrasi yang tinggi siswa benar-benar mendapatkan pengetahuan yang baik. Pemusatan pikiran merupakan suatu faktor penting dalam pendidikan Hindu. Hal itu karena menurut Narayana (1999, hlm. 15) jnana atau pengetahuan berarti pengertian, tetapi bukan sekedar prestasi kecerdasan. Makan bukanlah sekedar meletakan makanan di atas lidah. Kegiatan makan hanya akan bermanfaat bila makanan itu dikunyah, ditelan, dicernakan, diserap kedalam darah, kemudian diubah menjadi otot dan tulang, tenaga serta kekuatan. 
Gagasan Narayana tersebut memberikan suatu perumpamaan pengetahuan adalah seperti makan, pengetahuan yang tidak dicerna dan diresapi atau direfleksikan maka pengetahuan tersebut tidak akan dapat dipahami dan tidak dapat berguna dalam kehidupan sehari-hari. Pemusatan pikiran dalam pendidikan Hindu dilakukan dengan meditasi. Seseorang tidak akan berhasil dalam segala hal apabila tidak memusatkan pikiran terhadap sesuatu yang ingin dicapai. Meditasi merupakan kegiatan yang tidak mudah dilakukan, sehingga dalam pendidikan Hindu dilakukan suatu usaha pembiasaan untuk melakukan meditasi hal itu terlihat dengan adanya bentuk-bentuk kegiatan yang berkaitan dengan perenungan sebagai wujud penerapan meditasi dalam masyarakat Hindu, misalnya seperti tapa atau bertapa, yoga, samadhi dan lain-lainnya. Selain bentuk atau wujud penerapan meditasi tersebut, terdapat juga seperti dharana, dhyana dan samadhi. Ketiga wujud meditasi tersebut merupakan tiga tahap berturut-turut dari proses yang sama dari konsentrasi mental karena itu merupakan bagian dari keseluruhan organ. Dharana adalah usaha untuk memusatkan pikiran secara mantap pada suatu obyek. Dhyana merupakan pemusatan terus menerus yang tanpa henti dari pikiran terhadap obyek. Samadhi adalah pemusatan pikiran terhadap obyek dengan intensitas kosentrasi sedemikian rupa sehingga menjadi obyek itu sendiri. Pikiran sepenuhnya bergabung dalam penyamaan dengan obyek yang dimeditasikan.

Mengenai aspek-aspek aktivitas dalam meditasi dijelaskan oleh Chah (1995) yaitu sebagai berikut.

Saat duduk bermeditasi pikiran menjadi halus, tetapi kita harus tetap sadar dan mengetahui keadaan di dalamnya. Di sana beberapa aktivitas mental hadir bersama-sama dengan ketenangan. Antara lain Vitakka, yang membawa pikiran menuju dasar pokok perenungan. Apabila disana tidak terdapat kesadaran penuh, maka tidak aka nada vitakka. Lalu Vicara, perenungan sekitar pokok itu, mengikuti. Beragam pengaruh mental yang lemah dapat timbul dari waktu ke waktu dan kesadaran kita memegang peranan penting-apapun yang terjadi, kita selalu mengetahui. Makin lama kita akan selalu sadar terhadap keadaan meditasi mengetahui pikiran kokoh atau tidak, demikianlah kosentrasi dan kesadaran kedua-duanya hadir. Memiliki pikiran yang tenang bukan berarti tidak ada apa-apa sama sekali-pengaruh-pengaruh mental akan timbul. Misalnya pada waktu kita berada dalam ketenangan tingkat pertama, terdapat tiga factor lain yang ada bersama dengan vitakka dan vicara, yaitu piti, kegiuran yang timbul terhadap pokok perenungan dan kemudian sukha, kebahagiaan. Keempat keadaan ini muncul berbarengan di dalam pikiran yang telah mencapai ketenangan. Mereka muncul sebagai suatu keadaan. Faktor kelima adalah ekaggata, pemanunggalan batin pada obyek yang sangat kuat.

Manan atau meditasi dijadikan sebagai salah satu metode penting dalam pendidikan Hindu adalah untuk menumbuhkan keyakinan yang kuat terhadap sesuatu atau ilmu pengetahuan yang diberikan oleh guru melalui metode sravanam atau meminjam gagasan 
Berger (1994, hlm. 5) sebagai bentuk sosialisasi. Siswa melakukan meditasi atau manan atau dalam istilah Berger (1994, hlm. 5) disebut internalisasi. Sebagai bentuk sosialisasi sravanam merupakan penyampaian sesuatu atau pengetahuan kepada siswa oleh guru dimana siswa mendengarkan apa yang disampaikan oleh guru. Setelah pengetahuan sampai pada siswa sebagai bentuk proses sosial selanjutnya siswa menginternalisasi pengetahuan tersebut, sehingga menjadi pengetahuan yang dimilikinya. Manan atau meditasi atau memikirkan sesuatu untuk dapat diketahui dengan mendalam sehingga tepat gagasan Poedjawijatna (2004, hlm. 15) bahwa "manusia berpikir itu untuk tahu. Kalu ia berpikir tidak semestinya mungkin ia tidak mencapai pengetahuan yang benar. Tak seorangpun mencita-citakan kekeliruan."

Dalam proses tersebut menurut (Berger, 1994, hlm. 5) pengetahuan yang objektif mengalami pembatinan atau pencerapan menjadi pengetahuan subjektif dalam diri siswa. Pernyataan Berger tersebut memiliki makna bahwa pengetahuan yang awalnya merupakan realitas objektif selanjutnya menjadi realitas yang dimiliki oleh individu-individu siswa yang selanjutnya pengetahuan itu dapat diterapkan oleh siswa dalam kehidupan sehari-hari. Salah satu faktor penting dalam pendidikan adalah kemampuan siswa untuk fokus dan memusatkan pikiran pada pembelajaran. Metode manan atau meditasi merupakan salah satu bentuk metode yang penting selain untuk mengkaji apa yang telah disampaikan tetapi merupakan bentuk usaha untuk membiasakan diri untuk melatih dan mengendalikan pikiran untuk dapat terfokus.

Karena pikiran dalam sastra Hindu dinyatakan memiliki sifat sulit untuk diam. Setiap detik pikiran selalu beralih dan berloncat-loncat dari satu objek pikiran ke objek pikiran yang lain. Jaman, Sunarsih, \& Paranta (t.t., hlm. 48) pikiran diibaratkan sebagai permukaan laut dan jiva adalah dasar lautan. Jika permukaan laut riak dan gelombangnya besar, maka sulitlah bagi kita untuk mengetahui dasar laut tersebut, sebaliknya apabila permukaan laut itu tenang, jernih maka dasar laut tersebut akan tampak. Makna pernyataan tersebut bahwa untuk dapat mengerti dan memahami pengetahuan diperlukan suatu fokus atau perhatian dan ketenangan pikiran. Untuk memfokuskan pikiran maka dapat dilakukan dengan meditasi terhadap apa yang telah diajarkan.

Untuk tahap pertama sudah tentu siswa akan mengalami suatu kesulitan karena meditasi untuk dapat berhasil juga perlu pembiasaan. Dalam pendidikan Hindu manan atau meditasi dijadikan sebagai salah satu metode dalam pendidikan tentunya dengan tujuan siswa mampu membiasakan diri untuk berkosentrasi. Kosentrasi merupakan salah satu hal penting dalam pencapaian pengetahuan dan memahaminya. Metode selanjutnya setelah manan ialah 
Nididhyasana. Metode nididhyasana merupakan metode penerapan atau realisasi dari apa yang telah disampaikan dalam kehidupan sehari-hari. Adanya penerapan metode nididhyasana dalam pendidikan Hindu menunjukkan bahwa dalam pendidikan Hindu tidak hanya usaha untuk memberikan siswa pengetahuan tetapi juga bagaimana penerapannya dalam kehidupan realitas sosial yang sesungguhnya. Hal tersebut bertujuan supaya siswa nantinya setelah selesai pendidikan akan mampu hidup dalam masyarakat dengan baik dan berhasil.

Selain metode tersebut terdapat masih metode lain seperti mengalami langsung (praktyaksa), Melalui pemikiran logika (anumana), Umpama atau perbandingan dan melalui penjelasan guru (agama Pramana) (Keramas, 2008, hlm. 38; Pendit, 2007, hlm. 11). Di samping itu, dalam kitab-kitab suci Hindu seperti Purana juga memberikan suatu metode untuk mempelajari atau pengajaran Veda (Agama Hindu) sebagi berikut. Kitab Vayu Purana I.201 menyatakan bahwa hendaknya Veda dijelaskan melalui Itihasa dan Purana. Veda merasa takut kalau seseorang bodoh membacanya. Veda berpikir bahwa dia (orang bodoh) itu akan memukulnya (Kajeng,dkk, 2003; Titib, 2004, hlm. 9). Adanya metode pendidikan baik pengajaran amaupu belajar seperti disebutkan di atas mengindikasikan bahwa dari sejak awal pendidikan Hindu telah memiliki dan menerapkan metode-metode penyampaian atau pengajaran agama Hindu melalui lembaga-lembaga pendidikan keagamaan pada jaman dahulu.

\section{Kurikulum}

Kurikulum merupakan alat inti dari pendidikan dalam pendidikan dewasa ini. Berbagai usaha terus dilakukan untuk pengembangan kurikulum dalam pendidikan termasuk pendidikan skala internasional sampai pendidikan yang ada di negara-negara di dunia ini, termasuk Negara Indonesia. Kurikulum sebagai alat untuk mencapai tujuan pendidikan ternyata telah menjadi pokok pemikiran juga dalam pendidikan agama Hindu pada jaman dahulu. Adanya pengunaan kurikulum dalam pendidikan Hindu sejak jaman dahulu adalah tampak dalam setiap pendidikan agama Hindu jaman dahulu.

Aspek-aspek yang menjadi bagian dari kurikulum telah diterapkan dan dijalannkan dalam pendidikan Hindu. Aspek-aspek dalam kurikulum dewasa ini yaitu visi, misi, tujuan, standar kualifikasi kompetensi, capaian pembelajaran, rencana pembelajaran, silabus, dan Satuan Acara Pembelajaran. Kurikulum pendidikan Hindu yang telah dijalankan dapat terlihat bagaimana pendidikan agama Hindu dilaksanakan pada jaman dahulu. Pendidikan Hindu yang dilaksanakan walaupun tidak tertulis, namun tetap memiliki acuan seperti 
visinya, misinya dan tujuan, strategi dan metode pembelajaran serta isi atau mata pelajaran yang akan diberikan. Hal itu terbukti bagaimana pendidikan Hindu jaman dahulu telah memberikan kontribusi baik dalam kehidupan keagamaan maupu sosial kemasyarakataan pada saat itu.

Menurut Amala dkk. (2004, hlm. 43) bahwa kurikulum pendidikan Hindu pada masa dulu, walaupun didominasi oleh aspek-aspek keagamaan namun terdapat juga pelajaran yang bersifat duniawi. Hal semacam itu menunjukkan bahwa sudah sejak awal pendidikan Hindu memberikan muatan kurikulum yang mengaju kepada suatu kejelasan dalam pelaksanaan pendidikan. Kurikulum sebagai alat untuk mencapai tujuan pendidikan telah disesuaikan dengan kebermanfaatan pengetahuan dan pelatihan yang diberikan dalam pendidikan dengan kehidupan sosial kemasyarakatan dan juga kehidupan keagamaan. Kurikulum pendidikan Hindu dibentuk dan dirancang dan dikembangkan dengan prinsip holistik. Hal itu karena seorang guru dalam pendidikan Hindu merupakan seseorang yang memiliki kemampuan untuk melihat sesuatu. Seorang guru mengetahui hal yang diperlukan dan kemungkinan kedepannya, sehingga apa yang guru akan ajarkan mengacu pada kondisi dan situasi sosial kemasyarakatan dan keagamaan. Amala dkk. (2004, hlm. 43) menjelaskan materi-materi pelajaran yaitu:

Student were given knowledge of four Vedas-Rigveda, Yajurveda, Samaveda, and Atharvaveda. The syllabus took within its compass such subjects as spiritual as well as materialistic knowledge, Veda, Vedic Grammar, aritmatic, knowledge of gods, knowledge of absolute, knowledge of ghosts, astronomy, logic, philosophy, ethics, conduct, etc.

Pendapat tersebut di atas menunjukkan bahwa mata pelajaran yang diberikan dan diajarkan oleh para Guru dalam pendidikan agama Hindu merupakan suatu yang bersifat sesuai dengan konteks kebutuhan dalam situasi social kemasyarakatan pada jaman tersebut.penyataan tersebut sesuai dengan pendapat Shukla (2004, hlm. 74) bahwa "Curriculum was based on two aspect such as vocational studies and religious education. Certain subjects included in the curriculum were medicine, philosophy, science, history, astrology, art and archery, puranas, upanisad etc."

\section{Simpulan}

Pendidikan agama Hindu memang secara struktural dapat berarti Pendidikan dalam pandangan Hindu dan juga dapat bermakna Hindu dalam pandangan pendidikan. Keduanya memiliki makna yang berbeda. Pendidikan dalam pandangan Hindu berarti pendidikan yang 
mengunakan ajaran dan konsep-konsep Hindu sebagai landasan dan inspirasi untuk mengembangkan pendidikan, baik dari visi, misi, tujuan, capaian pembelajaran (learning outcome), metode pengajaran, strategi pembelajaran serta metode evaluasi dalam pendidikan Hindu. Ajaran serta konsep-konsep pendidikan yang ideal sangat banyak dalam Hindu. konsep-konsep pendidikan dalam hindu sepatutnya yang dikembangkan oleh lembaga lembaga pendidikan Hindu maupun guru-guru agama Hindu sehingga pendidikan agama Hindu benar - benar dapat mengwujudkan tujuan agama dan tujuan manusia dalam dunia ini. Pengembangan tidak berarti mengcopy paste tetapi melalui kreasi baru seperti pernah dilakukan oleh masyarakat Indonesia ketika mengkreasi ajaran agama Hindu sesuai dengan desa, kala dan patra sehingga memiliki ciri khas Hindu Indu Indonesia, demikian pula halnya dengan pendidikan Hindu. Makna Hindu dalam pendidikan berarti bahwa agama Hindu dilihat dengan mengunakan teori-teori pendidikan yang merupakan kebanyakan berasal dari Barat. Hal tersebut juga berarti bahwa agama Hindu atau pendidikan Hindu hanya dijadikan objek garapan dari pendidikan umum yang sudah tentu, tetap menjadi pendidikan umum bukan pendidikan Hindu.

Dilihat berdasarkan analisis dan pembahasan mengenai kedua makna pendidikan Hindu di atas, maka pendidikan Hindu lebih tepat dan semestinya dimaknai sebagai Pendidikan dalam pandangan hindu supaya dapat memunculkan pendidikan yang benar-benar mengedepankan religiusitas dan berguna bagi pengembangan agama Hindu guna dapat berkontribusi dalam ilmu pengetahuan yang dating dari Timur sebagai jawaban dan tandingan ilmu-ilmu barat dimana dalam era postmodern ini sedang bangkit gerakan-gerakan para ilmuan untuk memunculkan suatu ilmu yang memandang sesuatu dari dirinya sendiri.

\section{Daftar Pustaka}

Ahmadi, H. A., \& Uhbiyati, N. (1991). Ilmu Pendidikan. Jakarta: Rineka Cipta.

Altekar, A. S. (2009). Education in Ancient India. New Delhi: Isha Books.

Amala, P., Annie, P., Anupama, \& Rao, D. B. (2004). History of Education. New delhi: Discovery Publishing House.

Atmaja, A. T., \& Atmaja, N. B. (2008). Sertivikasi Guru: Memperkaya atau menyejahterakan? (Perspektif Semiotika Komunikasi). Jurnal Pendidikan dan Pengajaran, 41(1).

Atmaja, N. B. (2010). Dewatanisasi Insani: Pemaknaan Pendidikan Dalam Perspektif Filsafat Pendidikan Hindu. Jurnal Pendidikan dan Pengajaran, 43(7), 56-65. 
Awanita, M. (2003). Agama Hindu:Modul Orientasi Pembekalan Calon PNS. Jakarta: Proyek Pembibitan Calon Tenaga Kependidikan Biro Kepegawaian Sekretariat Jenderal Departemen Agama Republik Indonesia.

Berger, P. L. (1994). Langit Suci: Agama Sebagai Realitas Sosial. Jakarta: LP3ES.

Chah, V. A. (1995). Meditasi: Jalan Menuju Kebebasan. Jakarta: Yayasan Penerbit Karaniya.

Dvivedi, B. L. (1994). Evolution of Educational Thought in India. New Delhi: Northen Book Centre.

Haryanto, S. (2012). Spektrum Teori Sosial: Dari Klasik Hingga Postmodern. Yogyakarta: Ar-Ruzz Media.

Jaman, I. G. (2007). Tri Hita Karana dalam Konsep Hindu. Denpasar: Pustaka Bali Post.

Jaman, I. G., Sunarsih, W., \& Paranta, S. K. (t.t.). Membina Keluarga sejahtera (Grha Jagadhita). Surabaya: Paramita.

Jayapalan, N. (2005). History of Education in India. New Delhi: Nice Printing Press.

Jyoti, I. R. B. W. P. S. S. S. (2012). Reformasi Ritual: Mentradisikan Agama bukan Mengagamakan Tradisi. Denpasar: Pustaka Bali Pos.

Kajeng,dkk, I. N. (2003). Sarasamuscaya dengan Teks Bahasa Sanskerta dan Jawa Kuna. Surabaya: Paramita.

Kasturi, N. (1998). Pesan Pesan Upanisad. Surabaya: Paramita.

Keramas, D. M. T. (2008). Filsafat Ilmu. Surabaya: Paramita.

Lubis, A. Y. (2004). Filsafat Ilmu: Metodologi Posmodernis. Bogor: AkaDemia.

Machwe, P. (2000). Kontribusi Hindu Terhadap Ilmu Pengetahuan dan Peradaban. Denpasar: Widya Dharma.

Mas'ud, A. (2002). Mengagas Format Pendidikan Nondikotomik (Humanisme Religius sebagai Paradigma Pendidikan Islam. Yogyakarta: Gama Media.

Mookerji, R. K. (2003). Ancient Indian Education:Brahmanical and Buddhist. New Delhi: Srhi Jainendra Press.

Narayana, B. S. (1999). Pancaran Kasih Tuhan (Prema Vahini). Surabaya: Paramita.

O'Sullivan, P. G. (1997). Vedic Education (Gurukula) In a contemporary context:

Consideration for a Krisna Consious Thinking Curriculum. Melbourne: The University of Melbourne. 
Pandit, B. (2001). The Hindu Main: Fundamentals of Hindu Religion and Philosophy. New Delhi: New Age Books.

Pendit, N. S. (2007). Filsafat Hindu Dharma Sad Darsana: Enam Aliran Astika (Ortodoks). Denpasar: Pustaka Bali Post.

Piliang, Y. A. (2008). Posrealitas: Realitas Kebudayaan dalam Era Posmetafisika. Yogyakarta: Jalasutra.

Poedjawijatna. (2004). Logika: Filsafat Berpikir. Jakarta: Rineka Cipta.

Prabupada, A. . B. S. (1983). Bhagawadgita menurut Aslinya: Jawaban Segala Pertanyaan. Jakarta: P.T. Pustaka Bhaktivedanta.

Prabupada, A. . B. S. (t.t.). Nitisastra: Ungkapan-Ungkapan dari Canakya dan Hitopadesa penjelasan dari Satsvarupa Dasa Gosvami Sesuai dengan yang dikutif oleh Srila Prabupada.

Pudja, G. (2003). Bhagawad Gita (Pancama Veda). Surabaya: Paramita.

Puniatmadja, I. B. O. (2002). Pancha Cradha. Jakarta: Yayasan Dharma Sarathi.

Ra, A. (2004). Hukum Karma. Surabaya: Paramita.

Rao, D. B., \& Babu, E. S. (2004). Educational Interest of School Student. New Delhi: Discovery Publishing House.

Sadulloh, U. (2004). Pengantar Filsafat Pendidikan. Bandung: Alfabeta.

Shukla, R. P. (2004). Value Education and Human Right. New Delhi: Sarup \& Son.

Singh, Y. K., \& Nath, R. (2007). History of Indian Education System. New Delhi: S.B Nangia.

Sivananda, S. S. (1984). Religious Education. Himalayas: The Divine Life Society.

Somvir. (2001). 108 Mutiara Veda: Untuk Kehidupan Sehari-Hari. Surabaya: Paramita.

Suhardana, K. (2006). Pengantar Etika dan Moralitas Hindu: Bahan Kajian untuk Memperbaiki Tingkah Laku. Surabaya: Paramita.

Suhardana, K. (2007). Catur Purusa Artha: Empat Tujuan Hindup umat Hindu. Surabaya: Paramita.

Suhardana, K. (2010). Catur Guru Bhakti: Bhakti Kepada Guru. Surabaya: Paramita.

Sukayasa, I. W. (2011). Kembali Ke Spirit Hindu Indonesia. Denpasar: UNHI Denpasar.

Sukhabodhananda, S. (2006). Karma Yoga: The Inner Alchemy of Action. Bangalore:

Prasanna Trust.

Suparno, P. (1997). Filsafat Konstruktivisme dalam Pendidikan. Yogyakarta: Kanisius. 
Susanto, A. (2011). Filsafat Ilmu: Suatu Kajian dalam Dimensi Ontologis, Epistemologis, dan Aksiologis. Jakarta: Bumi Aksara.

Titib, I. M. (1996). Veda Sabda Suci : Pedoman Praktis Kehidupan. Surabaya: Paramita.

Titib, I. M. (2004). Purana: Sumber Ajaran Hindu komprehensip. Surabaya: Paramita.

Tutik, T. T., \& Trianto. (2008). Dimensi Transendental dan Transformasi Sosial Budaya. Jakarta: Lintas Pustaka.

Wardana, I. K., \& Relin. (2004). Buku Ajar Pengantar Filsafat. Jakarta: Dirjen Bimas Hindu dan Buddha. 